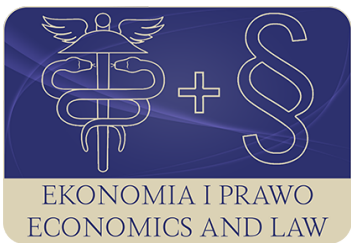

EKONOMIA I PRAWO. ECONOMICS AND LAW

Volume 18, Issue 2, June 2019

p-ISSN 1898-2255, e-ISSN 2392-1625

www.economicsandlaw.pl

EKONOMIA I PRAWO
ECONOMICS AND LAW

ORIGINAL ARTICLE

received 03.07.2018; revised 25.01.2019; accepted 30.06.2019

Citation: Czetwertyński, S. (2019). The gnoseological sense of a new paradigm of the institutional economics. Ekonomia i Prawo. Economics and Law, 18(2): 165-181.

doi:10.12775/EiP.2019.013.

\title{
The gnoseological sense of a new paradigm of the institutional economics
}

\author{
SEAWOMIR CZETWERTYŃSKI \\ Wrocław University of Economics, Faculty of Economic Sciences, Department of Microeconomics \\ and Institutional Economics, ul. Komandorska 118-120, 53-345 Wrocław, Poland \\ $\square$ slawomir.czetwertynski@ue.wroc.pl \\ (D) orcid.org/0000-0003-4078-0104
}

\begin{abstract}
Motivation: The gnoseological sense of a new paradigm, apart from the methodological and sociological sense, includes its the deepest essence. It is expressed in a process of forming and popularization of a paradigm. It includes essential factors of a particular paradigm which are reflected by its general sense. Revealing the essence of the gnoseological sense enables to reveal the main factors from the essential ones, which have been applied unintentionally. The same applies to new institutional economics when it is used without scientific reflection. An idea of revealing the essence of its (of the institutional economics) gnoseological sense is to reveal aspects of the individualism and the holism

hidden in it.

Aim: Goal of this paper is to reveal the essence of the outline of the gnoseological sense of the paradigm of the new institutional economics.

Results: Result of the study is presentation of relations between the individualism and the holism in the paradigm of the new institutional economics. The main conclusion is that the paradigm of the economics sui generis is not homogeneous, similarly to the social sciences. The new institutional economics derives a holistic perspective from the sociology, and individualistic one from the neoclassical economics. Consequently the new institutional economics is based on contradictory foundations (it is of dual nature); this

becomes clear at a detailed level of considerations concerning its paradigm.
\end{abstract}

Keywords: new institutional economics; paradigm; holism

JEL: Al0; Al2 


\section{Introduction}

Twenty century philosophers of science were very harsh when assessing the scientific nature of the social sciences. This issue was attacked by both, rationalists and relativists. A rationalist - K. Popper (2002, p. 123) accuses social sciences of being a 'soft' nature, pointing out poor level of their falsifiability. In turn, a relativist, T.S. Kuhn (2009, p. 39) called into question whether any discipline of the social sciences had achieved any paradigm and hence, status of a science. While criterion of demarcation of a science based on the falsifiability pretends to the name of the universal methodological rule, criterion of mono-convention is of pure consensual nature. However, relativists rejected scholarship of social sciences since they stated researchers of the social reality failed to determine all issues constituting a paradigm. It seems that K. Popper, even if found to be a severe guard of the rationalism and the objectivity in a science, in fact was less radical (Blaug, 1995, p. 51), since he did not discriminate any science because of its subject, but he focused on how a science creates its theories and how it established empirical bases for their falsifiability. In turn, T.S. Kuhn, in order to defend its revolutionary theory of science development had to assume that a human activity must not be a science since it is not coherent within a particular consensus, reflection of which is a paradigm. In other case no scientific revolutions would take place but a science would be in a permanent crisis.

It is unquestioned that the issue of a common paradigm for social sciences is not studied deeply. It is also unquestionable that it is difficult to compare the social sciences to physical ones, in relation to which T.S. Kuhn established his theory (Borkowska, 2016, p. 56). The hard line of T.S. Kuhn regarding the mono-conventionality is a symptom of idealization and it must not be considered factually. When considering it (the hard line) to be the idealization, one can find a leading factor which, in the T.S. Kuhn's opinion, forms up growth of a science, on the basis of growing crisis in a normal science which in turn leads to scientific revolution and subsequent time (period) of the normal science.

The T.S. Kuhn's concept, although it has been criticized many times, among others, by K. Popper (1970), S.E. Toulmin (1970; 1972, pp. 95-130) and J.W.N. Watkins (1970); mainly because of its nonexistence, turned out to be very intellectually stimulating and the paradigm has become commonly used term. Despite T.S. Kuhn, in order to defend his theory, and in order to respond to accusations regarding too small precision (Masterman, 1970, pp. 61-66) established a disciplinary matrix term, it has never been commonly accepted. In fact, from the paradigm term it is distinguished just by a more formal nature (Kuhn, 2009, pp. 308-309). A.F. Chalmers (1993, p. 123) points out that these terms (the disciplinary matrix and the paradigm) can be used interchangeably.

Apart from the mechanics of the T.S. Kuhn scientific revolution and his science criterion of demarcation, one needs to agree that research of a science as a paradigmatic structure is a heuristically productive job. In the field of social sciences paradigmacy shows how opinions on a human nature change and what 
factors are recognized to be the leading ones in terms of further actions. Observance of a typical normal scientific work in the field of the social sciences brings circumstances to state that, in practice, a series of paradigms exists. Such a thesis is promoted by G. Ritzer (1975, p. 158) in relation to the sociology, but is can be expanded into all of the social sciences. It is also opinion of S. Kozyr-Kowalski (2000, p. 27), who pointed out multi-paradigmacy of the sociology. G. Ritzer states that the sociology is a set of paradigms and the difference is made by the fact, which of them is the leading one. Similarly, it can be referred to economics, where many paradigms operate but one dominates the other ones. Multi-paradigmacy thesis of social sciences does not match the idealistic concept of Khun since basically, there does not take place a revolution, but temporary domination of a one paradigm over the other one. However, it should be noticed that in the concept of the multi-paradigmacy picture of the social sciences, paradigms are neither totally autonomic nor different. They are also not monoliths, which do not change internally. If they were totally different monoliths, the economic thought would not exceed the classic economics, into the neoclassical economics. Hence, a set of paradigms in economics is subject of transformations, resulting in new qualities.

T.S. Kuhn (2009, p. 162) considers the issues of establishing of new paradigms quite shallow, focusing mainly on the young age of revolutionists. More attention to the issue in question was paid by A. Motycka (1980, p. 37) writing about gnoseological sense of a paradigm. This sense (apart from the sociological and the methodological ones) is related with a process of paradigm establishing and popularization of it. The gnoseological sense is important because it enables to situate an individual paradigm in multi-paradigmatic science and hence, to define relations between them. Consequently, it is possible to discover capabilities and cognitive limits of a considered paradigm.

Goal of this paper is revealing the essence of the outline of the gnoseological sense of the paradigm of the new institutional economics. In order to achieve this goal in a priori way, there was assumed the paradigmatic dualism at the level called a general level, and the multi-paradigmacy of the social sciences - at a detailed one. Consequently, it was assumed that the social sciences comprise a set of detailed paradigms, dynamically balanced in relation to each other. It means that in a particular situation, a single paradigm has a primacy to the other one, while in other situation the primacy of the other one may take place. At the highest level just two general paradigms exist, essence of which is manifested by the methodological individualism and the methodological holism, and more accurately, in the radical individualism and the radical holism.

It was also assumed that diversity of a paradigm can be a constant attribute. It can be pictured as a system of axes. Vertical axis presents a paradigm development and a path of the paradigm development in time. Vertical axis is a spectrum one axis, on which, at a particular historical time, on one side there is a paradigm $X_{1}$, and on the other side there is $X_{n}$. Between them there are temporary stages: $X_{2}, X_{3}, X_{4}$ and so on till $X_{n-1}$. Looking at the paradigm on extreme 
sides of the horizontal axis may make an impression that these are different paradigms, while in fact these are different types of the same paradigm during particular time. It does not mean there cannot be more than one system of paradigmatic axis, and that these systems cannot penetrate each other, cross each other and mix with each other. In this paper two systems of axes are considered; they are related with the methodological individualism and the holism.

An idealization method was applied in this paper, and consequently, two groups of paradigms are examined: the detailed ones and the general ones. The detailed paradigms are concrete paradigms applied by scientists during their daily scientific work. They are the most different from ideal ones. In turn, general paradigms come close to the idealization and they include a total sense of the entire paradigm axes system.

\section{The gnoseological sense in the literature on economics}

The gnoseological sense of paradigms in social sciences has not been subject of deep research in a literature. In case of the triad of the social sciences (the economics, the sociology and the psychology), basically the issues in question are reduced (cut into) to a form of a history of thought. In the field of the economics, the most known attempt of establishing of the scientific thought development paths is a retrospective approach by M. Blaug (2000) presenting growth of a paradigm which could be called a neoclassical one. A similar attempt in Polish literature was made by J. Godłów-Legiędź (2010) in relation to the new institutional economics. In turn W. Stankiewicz (2014) writes about the institutional economics in a way characteristic for the historian of knowledge, hence, he focuses on a context of establishing (process) of a theory and its subsequent development. Nevertheless, these items do not focus on pre-ideas, which establish paradigms, but on a historical course of events and relations between them. From this point of view they are a research material for considerations herein.

An approach, which can be found similar to the gnoseological sense is presented by B. Scheuer (2015), however, his research area is economics sensu largo. The approach presented by B. Scheuer is based on a theory of L. Fleck (1986), which is assigned to a group of paradigmatic theories of science and which was established before the T.S. Kuhn's theory. With this regard B. Scheuer (2015, pp. 193-226) considers new thought styles, carriers of which are idea (bound) collectives; most of all this matches the sociological sense of the T.S. Kuhn's paradigms.

Considerations similar to looking for the gnoseological sense there are papers of J.W.N. Watkins (2001) and L. Nowak (1991), related with aspects of the methodological individualism and the holism. However, J.W.N. Watkins (2001, pp. 25-39) starts from the ideal types of Max Weber, heading for explanation of historical neoclassical considerations. In turn, L. Nowak (1991, pp. 284-286) very extensively develops a conceptual structure of the methodological individualism and the holism, omitting issue of assessment of the subject 
matter of economics. L. Nowak (1991, p. 286) differentiates the radical individualism and the radical holism.

Also papers of F. Znaniecki (1984) help to consider the gnoseological sense of paradigms in the field of the sociology of knowledge or the culture of science. F. Znaniecki (1984, pp. 397-442) differentiates six social roles of scientists that is: (1) a truth discoverer, (2) a systematist, (3) a controller, (4) a true soldier, (5) a knowledge propagator, (6) an eclecticism propagator and a historian of knowledge. First five roles concern a particular school or a paradigm from the perspective of T.S. Kuhn. The eclecticism propagator and the historian of knowledge, to the some point are regarded to be scientists beyond paradigms, or their paradigms are of an eclectic nature. According to such an approach there comes a multi-paradigmacy of science, which is divided by F. Znaniecki into 'schools'. His approach to a problem of differences in science and relations between communities of scientists is mainly of descriptive nature and not theory-making one. Hence, there dominates a description of particular roles of scholars. Worth of attention is a fact that every school has somebody, who established foundations for further development of a thought structure of such a school. Nevertheless, it does not have to be a particular person, sometimes an idea of the 'truth discoverer' is enough, enabling to assign to him/her discoveries of others as it took place among Pythagoreans (Tatarkiewicz, 1998, p. 53). In fact, the leading role of a discoverer is reduced to initiation of works of systematists and controllers who create something, what T.S. Kuhn calls a normal science. Truth soldiers and knowledge promoters defend and promote particular views assuring them their place in a structure of a science. F. Znaniecki's considerations reflect well the mechanics of emerging and establishing of paradigms in the sociological sense, however, they do not answer the question on how a truth is discovered. However, they penetratingly consider process of popularization of a particular doctrine, which can be treated as a form of a paradigm. Therefore, it is one of components of the gnoseological sense.

The gnoseological sense is different from the sociological sense; it contains a source of 'truth' - pre-ideas, arché. This source has a repercussion on the methodological sense of a paradigm - a paradigmatic theory, and this has the sociological sense. In the light of the methodology, it emerges in main assumptions of a paradigm - peculiar axioms or a hard core in the meaning of I. Lakatos (1978, p. 48), where non-falsifiability of assumptions is a kind of the methodological choice. In the sociological sense it will emerge in form of establishing of community of scientists focused on an individual paradigmatic theory. It should be noticed that process of self-keeping of the sociological sense of paradigm and its repeatability may result in fading away the gnoseological foundations. This phenomenon is characteristic for the social sciences contrary to the physical sciences, in particular physics. Operation within a factual plane - social and economic reality makes that foundations of the paradigmatic theory are brought to a background and one focuses on tools and temporary methods of solving of normal science puzzles. 


\section{Idealization method and gnoseological sense}

In this paper, a method of discovering of the gnoseological sense regarding the new institutional economics is the idealization method proposed by L. Nowak (1977) in the idealization theory of science. The idealization method means identification of factors substantial for studied phenomenon, and next, elimination (by means of idealization assumptions) of those, which are secondary ones. Hence, those, which make an essence of a phenomenon unclear, will be rejected and there remain only factors or a leading factor (general) which describes the essence of a phenomenon (an examined value). In this way there are rejected all disturbances and a relation is discovered, which can be formed up as a principle (Nowak, 1977, pp. 9, 22-23, 52-54). This principle is as long true as long its starting conditions are true (Kuciński, 2010, p. 16), therefore, an idealization essence is true as long as idealization assumptions are effective. Main problem of the idealization method is the ontological perspective which is accepted by one applying it. Such an ontological perspective will shape a classification into leading and secondary factors. The better assessment, the better ontological perspective is. In case of looking for the gnoseological sense, the ontological perspective must origin from the historical \& methodological extent. The historical one since the way a paradigm forms up itself is a historical process - lasting and embedded in a certain period characterized by certain phenomena. The methodological one since methodological factors give five basis for the paradigmatic theory.

In this context, the idealization method shall be subject of a cut reconstruction - from a particular picture of the new institutional economics to its ideal form included in basic theoretical assumptions and a development trajectory. The reconstruction requires elimination of all factors, which are of secondary nature compared to main assumptions and the direction of the thought development.

In a methodological extent of considerations herein, apart from the method also concrete view of the paradigmatic structure of the social sciences was taken into account. As it was already mentioned, multi-paradigmacy in the field of the social sciences including economics has been presumed. However, multi-paradigmacy is relevant for a detailed stage which is far away from the ideal one (factual, from factually existing one). It is a stage of a normal research work which is daily practice of research works. At the general stage, which is the most similar to the ideal one, there exists only a paradigmatic dualism which is discovered when applying the idealization method.

Detailed way of multi-paradigmacy picture of a science can be illustrated by means of a system of axes presented in the chart 1 . The $t$ axis presents time, and more accurately, subsequent periods. In turn, the $X$ axis pictures the multi-paradigmacy which is a collection of paradigms from $X_{1}$ to $X_{n}$. The $X$ axis is the spectrum axis of the paradigmatic structure for a particular time. In the chart 1 this is a spectrum for the time $t_{0}$. The system of the paradigmatic 
structure reflects paths of development of the paradigms within time, similarly to a collective thought lines proposed by L. Fleck (1986, p. 50). Thought collectives, which are equivalents of the paradigms from the T.S. Kuhn's theory (mainly to its sociological extent), transform as an effect of mutual affection among particular collectives. L. Fleck (1986, pp. 142-143) calls it a 'lines crossing' or an 'inter-collective exchange', which results in change in the thought value and hence, a new quality form. The interpretation of development of paradigms proposed in the chart 1 shows that paths of the paradigm can be relatively simple, they can split, bound or contact each other incidentally. One should take into account that relations do not always concern two groups of paradigms maximally, but larger groups as well.

The paradigmatic structure spectrum presented in the chart 1 concerns the detailed level only. However, the general stage is presented in the chart 2, which presents the essence of the idealization method. If $k$ means the factual level, therefore, such one where detailed paradigms exist, then 0 means the idealization level. At the each subsequent idealization level, number of paradigms will go down. Also level of details will be smaller and smaller, which means they are more and more general. Finally, according to assumptions made herein, at the idealization stage there are two paradigms left — the radically individualistic one and the radically holistic one.

When assuming the paradigmatic structure at the detailed level and the general one, discovering of the gnoseological sense will mean tracking of the paradigmatic paths and simultaneously, the idealization. It is supposed to enable determination on where the paradigm of the new institutional economics come from and, at the same time, what is its relation with the paradigmatic dualism of the general level.

\section{The idealization of a paradigm of the new institutional economics}

It is not possible to include the output of the new institutional economics in a single paper, especially that there is no full consensus when it comes about its extent. One should remember that the term: institutional economics is considered to be an institutionalism (called, e.g. old, classic, traditional, Veblenian, original, American one (Hodgson, 2004, p. 3; Stankiewicz, 2014, pp. 10, 12-16), the new institutionalism (also called a neo-institutionalism (Ratajczak, 1994, pp. 27-39)) and the new institutional economics. However, this classification is not accurate. In varied papers and materials one can find varied extents of this classification. E.g. M. Ratajczak (1994, pp. 28-29, 34-37; 2006, pp. 13-14) clearly distinguishes the institutionalism and the neo-institutionalism and the new institutional economics, while G.M. Hodgson (1989, pp. 250251; 2004, pp. 5-6, 257-259) distinguishes only an original institutionalism, and he calls the new institutional economics to be the new institutionalism. A disputable issue is also understanding of the new institutional economics itself; 
it can be interpreted only as a neoclassical institutional economics or as a resultant of the institutionalism and the neoclassical economics (Staniek, 2017, p. 22). De facto it is not clearly and unquestionably determined, what is a relation of the new institutional economics against the original institutionalism considered to be compilation of the 'old' and the 'new' ones, or more extensively, as a relation of the new institutional economics and the institutionalism and neo-institutionalism. More extensively there are discussed issues of differences between opinions of different economists, who are regarded to be representatives of particular streams. It is context where it is possible to distinguish new-institutionalists from institutionalists or institutionalists from representatives of the new institutional economics. This is possible only in terms of particular issues and not generally.

Just an attempt of presentation of the new institutional economics is automatically a simplification of it, and acceptance of an arbitrary classification. Focus on particular aspects, such as an institutional balance (Rudolf, 2017, pp. 22-35; Staniek, 2017, pp. 88-89; Sukiennik et al., 2017; Wilkin, 2011, pp. 2537), an adaptive efficiency (Godłów-Legiedź, 2010, pp. 74-76; North, 2014, pp 7, 73-82), or resources of common pool (Czetwertyński, 2013; Ostrom, 2013, pp. 1-4, 7-9, 39-54) generally assumes, that some of essential factors must had been considered to be secondary and they were eliminated from considerations at the very beginning. Separation of all of elements forming a part of the new inquisitional economics is a tough task, especially that authors, who carry out the synthesis, more or less consciously — present a hierarchy of essential factors and they select those which are the most important ones in their opinions. Hence, a path to the idealization must be and should be started from initially prepared research material. In this case one may use books comprising the synthesis of the output of the new institutional economics. The most important ones are: Handbook of new institutional economics edited by C. Ménard \& M.M. Shirley (2005), Institutions \& economic theory: the contribution of the new institutional economics by E.G. Furubotn \& R. Richter (2005) as well as New institutional economics: a guidebook edited by É. Brousseau \& J.-M. Glachant (2008b). Moreover, the following ones should be mentioned: Ekonomia instytucjonalna (Institutional economics) by W. Stankiewicz (2014), Wspótczesna ekonomia. Ku nowemu paradygmatowi? (Contemporary economics. Towards a new paradigm?) by J. Godłów-Legiędź (2010) and Ekonomia instytucjonalna. Czemu instytucje są ważne? (Institutional economics. Why institutions are important?) by Z. Staniek (2017).

One should take into account that a primary picture is the reality itself, with its entire complicated structure, relations, feedback and recursions. At this thought level, the most far away from the idealization, it is not possible to find the essence. Everything is important and at the same time, nothing is a principle. This material can be filtrated at the very beginning showing, what is subject-matter of the interests of scientists focused on the new institutional economics. É. Brousseau and J.-M. Glachant (2008a, p. xli) synthetically show three main groups of the subject of research. These are (1) organizations, (2) 
contracts and (3) institutions. After all, this is not a generalization, but a part of a detailed picture. If more detailed review was made focused on issues referred to in the afore mentioned books, the following ones would be considered to be important: a structure and institutional systems, formal and informal institutions, property rights - absolute ones and relative ones, governing, common pool resources, institutional stability and institutional equilibrium, an institutional matrix, path dependent, political institutions, a country, companies, a market, contracts, transactional costs, private solutions, arbitrary solutions, efficient adaptation etc. However, from this so chaotic set a single principle emerges. It means structuring of categories, such as classification into formal and informal: institutions, contracts (cf. social contract (Furubotn \& Richter, 2005, p. 494)); and then, the synthesis into a system of institutional ones, or an institutional matrix. Other example of the structuring is classification into the private and national: organizations, resources and solutions. Or into individual and common, as in case of resources, but also in case of the public choices (Furubotn \& Richter, 2005, p. 351). And obviously, into the market and non-market ones, which is reflected in form of the transactional costs economy.

Systematization and structuring of the subject of research enables to present it but it does not reveal a leading factor shaping a particular paradigm. In order to reveal it, next categories must be eliminated. And hence, after liquidation of the formal and informal classification, by implementing an assumption that between those values there exists equivalence, one can acquire a group of factors where the ownership is perceived as an individual or collective prism instead a form of law or a custom. Similarly, contracts must be examined individually, without practical enforcement of them. Then, there comes an abstractive picture, without considering factual solutions of a social \& economic 'daily life'. The subsequent elimination procedure is liquidation of a classification into 'private' and 'national', by applying an assumption that no social agreement exists. Consequently, every decision arises from rationality of an individual with reference to abstractive institutions, and not from factual compulsion produced by authorities. When it comes about disposal of resources, they will come as existing (material) or already developed (non-material) set. At this moment there must be eliminated a division between material and non-material perception of the resources, and they must be considered to be resources themselves. Elimination of the classification into market ones and non-market ones takes place simply by presuming the transactional costs to equal zero. Consequently, all relations will be of market nature meaning transfer of the ownership by means of a contract.

From a picture cut in such a way it is easier to derive leading factors and to consider them later. For sure these are the institutions, market and resources. As an effect of elimination of the transactional costs (at the lower level of idealization, hence, at the higher concretization level), costs of acquisition of information (criterion of the rationality) are acquired, responding to the tangible rationality. 
As an effect, the picture of the new institutional economics is cut into the rational issue of allocated resources via a market and participated by institutions. This picture of the institutional economics, close to the idealization, is different from a neoclassical paradigm only in the aspect of institutions. To the large extent it matches texts of E.G. Furubotn and R. Richter (2005, pp. 505-506) stating that frameworks of the neoclassical economics have been extended by the institutional dimension. It means that in the neoclassical paradigm institutions were of passive nature while in the new institutional economics they are of active nature.

Referring to the demarcation issue presented at the beginning, in the widely considered institutional economics it should be assumed that the new institutional economics is a sort of a resultant of the original institutionalism, recognized as a constructive synthesis of the old and the new institutionalism, and the neoclassical economics with excluded assumption of no institutional impacts (the neoclassical institutional economics). Referring to considerations of Z. Staniek (2017, p. 22-23) it is possible to classify main theories of the new institutional economics in such a way to show, which ones of them are ranked into the stream of the original institutionalism, and which ones into the neoclassical institutional economics (table 1). Proposed classification is arbitrary to some extent, however, it points out a balance point of considerations. In the original institutionalism the evolution approach dominates while in the neoclassical institutional economics, the modelling is a dominating approach. In fact this is issue of the methodological sense of the paradigm of the new institutional economics, however, distinguished at the detailed level. When it comes about approach coming closer to the idealization, there comes just a relation between the economic result and the institutional circumstances. Nevertheless, when it comes about the reductionism, there comes the original institutionalism at first, and then the neoclassical institutional economics, and finally the institutional economics sui generis. It is logic since the neoclassical economics, which the neoclassical economics derives from, is seriously cut which means there are a lot of idealizing assumptions at the detailed level — this is an inheritance of the neoclassical economics.

Coming back to the leading factors in the new institutional economics that is institutions, a market, resources and the rationality, it should be mentioned that subsequent reduction leads to selection of the single factor only. Reduction (cutting) way is not possible according to a universal criterion. At the present level of the idealization there are four types of factors: (1) holistic that is an institution; (2) mechanistic, the market considered as the allocation process; (3) material, referring to resources; and (4) deterministic, perceived as a rational action. Depending on an assumed ontological perspective (Nowak, 1977, pp. 72-80), hence, an essential structure of assumptions, the idealization process will vary. One must not process the abstractive reality without a reference to theories; similarly, 'naked' facts cannot be observed (Fleck, 1986, pp. 114, 133). Consequently, subsequent cut can take place at two stages, 
in the spirit of the individualism and the holism. In both cases it is possible to eliminate factors: the market and the resources. Therefore, there remain the issues of the institutions and the rationality. In case of institutions, an essence of the new institutional economics were institutions, as the sole one determinant of human activity. Consequently, all individual selections and global circumstances were caused by quality and efficiency of the institutions. In case of the rationalism the thought process shapes reversely. All decisions are made individually and institutions pose a resultant of these decisions.

It must be stated the rationalism does not exclude institutions at lower stages of the idealization. It means, however, essentialism of individuals instead of the entirety. It must be referred to the considerations of L. Nowak (1991, pp. 284-285) regarding the methodological individualism and the holism. L. Nowak specifies the considerations by looking into existential and essential dimensions. At the essential dimension, the individualism means there exist attributes of individuals only. However, the attributes of the entirety are attributes of higher rank individuals. To express it more clearly, there exist individuals and entireties, but the latter have no attributes themselves. Their attributes in fact are attributes of higher rank individuals. It also should be specified that attributes of individuals not always cumulate linearly to the higher ranks. Transfer of them makes that an attribute of an individual is not an attribute of the entirety but a change of it, and moreover, the change in question may be diametrical. Process of this change is a relation between individuals. In extent of the essential holism, the entireties themselves have attributes irrespective of attributes of individuals. The entirety is a carrier of an attribute and change of it is its feature (of the entirety). Individuals do not implement a change since they act in line with the attribute of the entirety. Alteration of attributes of the entirety takes place according to relations between the entireties.

At this point there comes a gnoseological sense of a new paradigm of the institutional economics and included contradiction. Choice between the leading factor is a choice between the essential individualism and the holism, with consideration given to the existential holism (it states there are individuals and entireties). In case of choice of the essential individualism, a leading factor is the rationalism. Consequently, individuals establish institutions along with their higher rank attributes. The way the higher rank attributes are established is issue of institutions as the entirety and subject-matter of the research. In case of the essential holism the leading factor are institutions, attributes of which are reflected in individuals.

\section{Conclusions}

The gnoseological sense of a new paradigm of the institutional economics is included in the internal opposition of the approach of the essential individualism and the essential holism. It could seem that two contradictory ideas at the basis of a paradigm can be a source of a kind of the 'bipolar disorder'. However, es- 
tablishing of philosophical systems based on opposites is heuristically fertile. The opposite stimulates dynamics, lack of which is suffered by e.g. the neoclassical economics. The dynamics in question means continuous alteration of individuals and entireties at all levels of details. The higher level of details, the more clear the contradiction is. At the level of the normal science, in the framework of the scientific daily work it can be totally unnoticeable. It results from the fact that considering of a particular issue in the light of the new institutional economics will not result in reflections concerning attributes of the institutions. Whether or not the institutions have attributes themselves or whether or not these are attributes of higher rank individuals can be insignificant in the context of explanation of a detailed phenomenon. In other words, not every subject-matter of research requires determination whether rules of game are more important than players, or whether players develop rules of the game during the process of transfer of attributes into higher ranks.

Considerations regarding nature of attributes of institutions are significant at the institutional environment level or more embeddedness level in O.E. Williamson's (2000, p. 597) four-level concept of the social analysis. At the stage of governance, or allocation of resources and employment they are factors shaded by factors considered to be secondary ones at the idealization process. In case when subject-matter of the research is the embedding or the institutional environment, hence, they are of nature of the social theory, or more accurately, the new institutional economics, economics of the ownership rights and the positive theory of politics, then the essence of the individualism and holism become significant. Contrasting these two categories stimulates heuristic ability to draw conclusions on relations between the entireties and individuals, that is between individuals and institutions.

At the end of considerations there must be summed up issues of the continuity of paradigms and determination of a paradigm of the new institutional economics in sensu largo economics and the social sciences. Multi-paradigmacy in economics must be referred to the neoclassical economics, since the latter, because of its strong formalism, is clearly embedded within its boundaries. It is also important it is called the orthodoxy. Fact that this is a starting point has its reasons not in its rightness but in chronology of development. Since the gnoseological sense does not result from itself and the paradigms are not formed up on the basis of metaphysical feelings, it must be taken it account that the neoclassical economics must have had an impact on the paradigm of the new institutional economics on the temporary basis. The serious pressure on the methodological individualism is characteristic for the neoclassical economics, even if usually it is not revealed in the essential approach. In turn, the methodological holism called by J.W.N. Watkins (1957, p. 106) the sociological holism, arises directly from the methodological sense of extensively considered sociological paradigm, hence, related with the idea of É. Durkheim and his concept of the society as the entirety sui generis. 
Paradigmacy in economics comes on the basis of out of focus indistinct gnoseological sense, methodological and sociological ones. It seems that for economics, the rationalism and the individual connotation are on the top. However, the paradigmatic unity is very apparent and it depends on the level of relations. The more deeply one looks into the economics, the more apparent the variation of the paradigm becomes. It can be compared to a picture which, from a distance seems to be a green spot while when one comes closer, shades of colors become noticeable. Similarly the situation concerns the sociology, however, a leading issue in this case is a norm meaning social control and its historical connotation. The paradigm of the new institutional economics is not gnoseologically autonomous and it is not embedded in a single science. It covers economics and the sociology, and when examined more deeply, the psychology, the law and other social sciences. Its sharpness is relative depending on what lens is used to look into it.

\section{References}

Blaug, M. (1995). Metodologia ekonomii. Warszawa: PWN.

Blaug, M. (2000). Teoria ekonomii. Ujęcie retrospektywne. Warszawa: PWN.

Borkowska, B. (2016). Nowa ekonomia instytucjonalna w dydaktyce. Studia $i$ prace WNEiZ US, 44(2). doi:10.18276/sip.2016.44/2-04.

Brousseau, É., \& Glachant, J-M. (2008a). A road map for the guidebook. In É. Brousseau, \& Glachant, J-M. (Eds.), New institutional economics: a guidebook. New York: Cambridge University Press. doi:10.1017/ CBO9780511754043.002.

Brousseau, É., \& Glachant, J-M. (Eds.) (2008b). New institutional economics: a guidebook. New York: Cambridge University Press. doi:10.1017/ CBO9780511754043.

Chalmers, A.F. (1993). Czym jest to, co zwiemy nauka? Wrocław: Siedmioróg.

Czetwertyński, S. (2013). Cyfrowe zasoby wspólnej puli w gospodarce informacyjnej. In K. Kreft, D. Wach, \& J. Winiarski (Eds.), Systemy informatyczne w gospodarce. Gdańsk: Uniwersytet Gdański.

Fleck, L. (1986). Powstanie i rozwój faktu naukowego. Lublin: Wydawnictwo Lubelskie.

Furubotn, E.G., \& Richter, R. (2005). Institutions \& economic theory: the contribution of the new institutional economics. Ann Arbor: The University of Michigan Press.

Godłów-Legiędź, J. (2010). Wspótczesna ekonomia. Ku nowemu paradygmatowi? Warszawa: C.H. Beck.

Hodgson, G.M. (1989). Institutional economic theory: the old versus the new. Review of Political Economy, 1(3). doi:10.1080/09538258900000021.

Hodgson, G.M. (2004). The evolution of institutional economics: agency, structure and Darwinism in American institutionalism. London-New York: Routledge. 
Kozyr-Kowalski, S. (2000). Socjologia spoteczeństwo obywatelskie i państwo. Poznań: UAM.

Kuciński, K. (2010). Istota nauk ekonomicznych. In K. Kuciński (Ed.), Metodologia nauk ekonomicznych. Dylematy i wyzwania. Warszawa: Difin.

Kuhn, T.S. (2009). Struktura rewolucji naukowych. Warszawa: Aletheia.

Lakatos, I. (1978). The methodology of scientific research programmes. In J. Worrall, \& G. Currie (Eds.), Philosophical papers, Volume 1. CambridgeNew York: Cambridge University Press.

Masterman, M. (1970). The nature of a paradigm. In I. Lakatos, \& A. Musgrave (Eds.), Criticism and the growth of knowledge. Cambridge: Cambridge University Press.

Ménard, C., \& Shirley, M.M. (Eds.). (2005). Handbook of new institutional economics. Boston: Springer.

Motycka, A. (1980). Relatywistyczna wizja nauki. Analiza krytyczna koncepcji T.S. Kuhna i S.E. Toulmina. Wrocław: Zakład Narodowy imienia Ossolińskich.

North, D.C. (2014). Zrozumieć przemiany gospodarcze. Warszawa: Wolters Kluwer.

Nowak, L. (1977). Wstęp do idealizacyjnej teorii nauki. Warszawa: PWE.

Nowak, L. (1991). U podstaw teorii socjalizmu. Dynamika wtadzy: o strukturze $i$ konieczności zaniku socjalizmu. Poznań: Nakom.

Ostrom, E. (2013). Dysponowanie wspólnymi zasobami. Warszawa: Wolters Kluwer.

Popper, K. (1970). Normal science and its dangers. In I. Lakatos, \& A. Musgrave (Eds.), Criticism and the growth of knowledge. Cambridge: Cambridge University Press.

Popper, K.R. (2002). Logika odkrycia naukowego. Warszawa: Fundacja Aletheia.

Ratajczak, M. (1994). Nurt instytucjonalny we współczesnej myśli ekonomicznej. Ruch Prawniczy, Ekonomiczny i Socjologiczny, 56(1).

Ratajczak, M. (2006). Miejsce instytucjonalizmu we wspótczesnej ekonomii. In U. Zagóra-Jonszta (Ed.), Dokonania wspótczesnej myśli ekonomicznej. Ekonomia instytucjonalna: teoria i praktyka. Katowice: AEw Katowicach.

Ritzer, G. (1975). Sociology: a multiple paradigm science. The American Sociologist, 10(3).

Rudolf, S. (2017). Nowe spojrzenie na równowagę instytucjonalną i zmianę instytucjonalną. Prace Naukowe UE we Wroctawiu, 493. doi:10.15611/ pn.2017.493.02.

Scheuer, B. (2015). Metodologia ekonomii w perspektywie konstruktywistycznej. Wrocław: UE we Wrocławiu.

Staniek, Z. (2017). Ekonomia instytucjonalna. Dlaczego instytucje są ważne? Warszawa: Difin.

Stankiewicz, W. (2014). Ekonomia instytucjonalna. Zarys wykładu. Warszawa: AON. 
Sukiennik, J., Dokurno, Z., \& Fiedor, B. (2017). System instytucjonalnej równowagi a proces zmian instytucjonalnych z perspektywy zrównoważonego rozwoju. Ekonomista, 2.

Tatarkiewicz, W. (1998). Historia filozofii. Filozofia starożytna i średniowieczna. Warszawa: PWN.

Toulmin, S.E. (1970). Does the distinction between normal and revolutionary science hold water? In I. Lakatos, \& A. Musgrave (Eds.), Criticism and the growth of knowledge. Cambridge: Cambridge University Press.

Toulmin, S.E. (1972). Human understanding. Volume 1: general introduction and part I. Oxford: Clarendon Press.

Watkins, J.W.N. (1957). Historical explanation in the social sciences. The British Journal for the Philosophy of Science, 8(30).

Watkins, J.W.N. (1970). Against 'normal science'. In I. Lakatos, \& A. Musgrave (Eds.), Criticism and the growth of knowledge. Cambridge: Cambridge University Press.

Watkins, J.W.N. (2001). Wyjaśnianie historii. Indywidualizm metodologiczny i teoria decyzji w naukach spotecznych. Wrocław: UW.

Wilkin, J. (2011). Institutional Equilibrium. What is it About and What is its Role in the Economy? Prace Naukowe UE we Wroctawiu, 3(15).

Williamson, O.E. (2000). The new institutional economics: taking stock, looking ahead. Journal of Economic Literature, 38(3). doi:10.1257/jel.38.3.595.

Znaniecki, F. (1984). Spoteczne role uczonych. Warszawa: PWN.

\section{Acknowledgements}

Author contributions: author has given an approval to the final version of the article.

Funding: this research was funded by the Wrocław University of Economics, Faculty of Economic Sciences, Department of Microeconomics and Institutional Economics statutory sources.

Note: the results of this study were presented at Second Scientific Conference Institutions: theory and practice (June, 19-20 2018, Torun, Poland). 


\section{Appendix}

\section{Table 1.}

\section{Selected theories of the new institutional economics divided into streams}

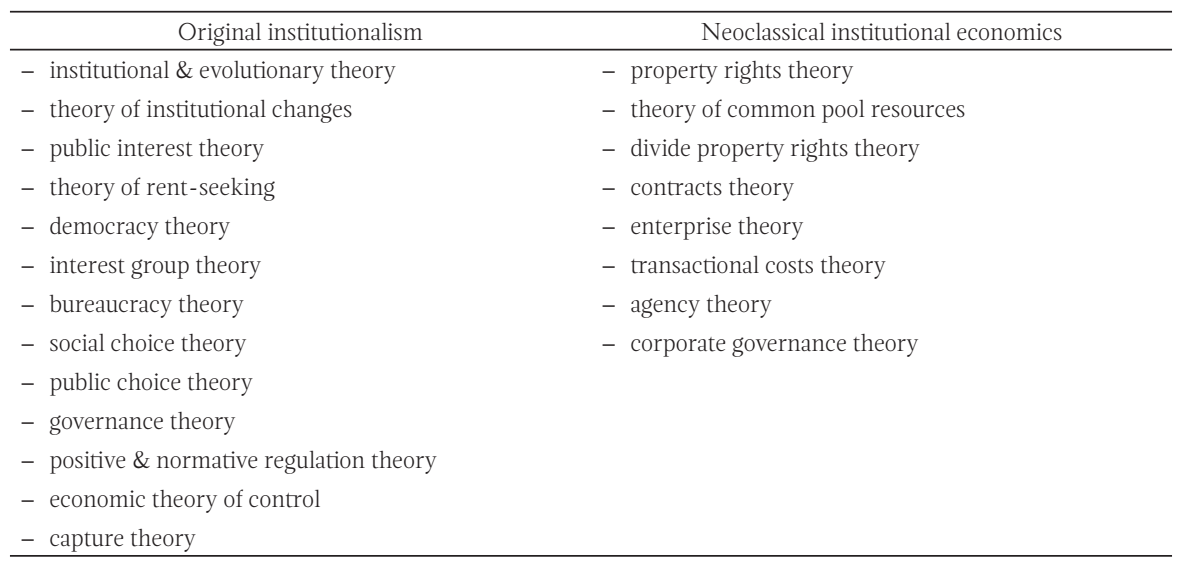

Source: Staniek (2017, pp. 22-23).

Chart 1.

Spectrum of the structure of paradigmatic paths

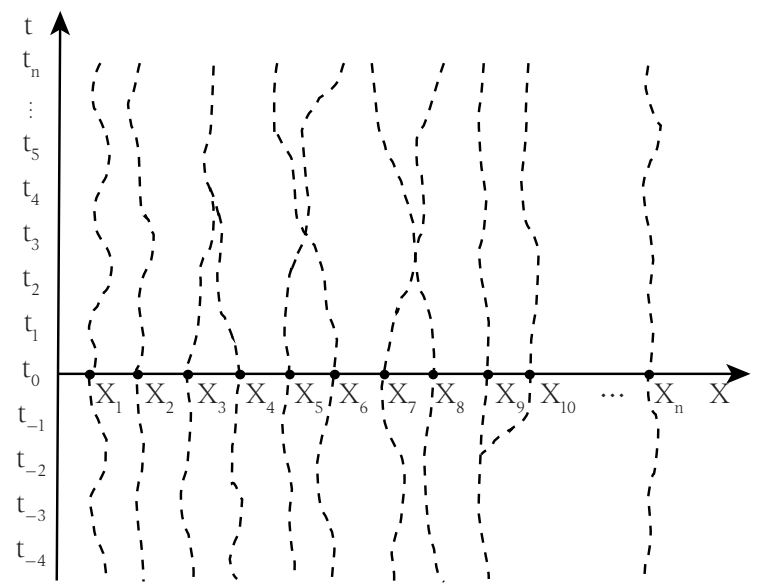

Source: Own preparation. 


\section{Chart 2.}

The essence of the idealization method

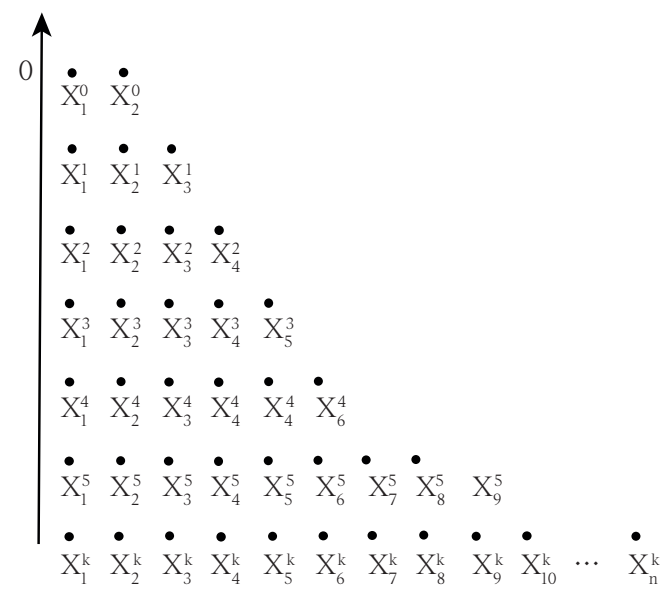

Source: Own preparation. 
